\title{
Biological Notes on Jerboas Allactaga euphratica and Jaculus jaculus from Iraq
}

\author{
A. H. KADHIM, A. M. MUSTAFA \& H. A. JABIR
}

\begin{abstract}
Kadhim A.H., Mustafa A.M. \& Jabir H.A., 1979: Biological notes on jerboas Allactaga euphratica and Jaculus jaculus from Iraq. Acta theriol., 24, 8: 93-98 [With 1 Table \& 3 Figs.]

Activity and moulting of two species of jerboas, Allactaga euphratica Thomas, 1881 and Jaculus jaculus (i: n n a e s, 1758) were studied in the vicinity of Samara (122 km. $\mathrm{N}$ of Baghdad) in Iraq during the period from January to December 1977. The differences in the circadian rhythm of activity of these two species were stated. Jaculus jaculus was seldom active during the warm season (June-August), whereas Allactaga euphratica was inactive during the cold season (November - January). Both species moult once a year, i.e. during July in $\boldsymbol{A}$. euphratica and September-October in J. jaculus.
\end{abstract}

[Sci. Res. Found., Biol. Res. Centre, Adhamiya, Baghdad, Iraq].

\section{INTRODUCTION}

Rodent family Dipodidae is represented in Iraq by two species: the Euphrates Jerboa, Allactaga euphratica Thom as, 1881 and the Lesser Jerboa, Jaculus jaculus (L i n n a e u s, 1758).

A. euphratica is distributed in the central and probably in the southern region of Iraq ( $\mathrm{K}$ a d h i m et al., 1977). The authors collected specimens from Samara, Dholuiya, Dour, Tikrit, Baiji and Hatra. $\mathrm{H}$ a r r is on (1972) noted specimens collected in Baqubah, Bahdad and Ramadi. H a t t (1959) noted a specimen from Abureb preserved in the Natural History Museum in Baghdad. Typical biotopes of the Euphrates Jerboa are shores of wadis and grassy fragments of hamada-type desert in hilly regions (A t a ll a h, 1967). Wherever it coexists with the Lesser Jerboa it is less common ( $\mathrm{H}$ a $\mathrm{r} \mathrm{r}$ is o $\mathrm{n}, 1972$ ).

The northern limit of distribution of Jaculus jaculus runs through Iraq, where it populates all the flatland of this country. The authors collected specimens from Al-Zubair, Safwan, Salman, Afaq, Badir, Niffar, Samara, Dholuiya, Dour, Tikrit, Baiji, Annajaf Sahara and Hatra. Harrison (1972) reported specimens from Haur al Hasa, S of Habaniya and Zobair. This rodent can be met in sandy desert but also in stony steppes (L e w is et al., 1965).

Studies on the biology and ecology of these Dipodids have not been 
done so far in Iraq. The aim of this work was the study of some aspects of their biology, mainly moulting, activity and behavior.

\section{MATERIAL AND METHODS}

Eighty five specimens of Allactaga euphratica and fourty five of Jaculus jaculus were collected in Samara $(122 \mathrm{~km} \mathrm{~N}$ of Baghdad) from January to December 1977. Small insect nets (32 cm in diameter) were used for catching the jerboas. When the animal runed away and entered the burrow we poured water in it in order to get the jerboa to go out. Catching was done in four-hours periods one hour after sunset (2-4 nights monthly). The car was driven along the tracks until a jerboa was seen in the head-light. As the car slowed down the catchers jumped out, one of each side and attempted to surround the animal. Sometimes it was easy to place the net over it, but more often the jerboa (especially Jaculus jaculus) run off. This procedure was repeated until the jerboa was either captured

Table 1

Number of seen and trapped individuals of Allactaga euphratica and Jaculus jaculus in particular months of 1977 in Samara.

\begin{tabular}{lrrrrr}
\hline & \multicolumn{2}{c}{ A. euphratica } & & \multicolumn{2}{c}{ J. jaculus } \\
\cline { 2 - 3 } \cline { 5 - 5 } Months & Seen & Trapped & & Seen & Trapped \\
\hline January & 0 & 0 & 7 & 3 \\
February & 17 & 9 & 11 & 4 \\
March & 16 & 15 & 8 & 3 \\
April & 18 & 12 & 8 & 4 \\
May & 18 & 10 & 13 & 4 \\
June & 27 & 7 & 6 & 2 \\
July & 21 & 10 & 5 & 4 \\
August & 21 & 7 & 6 & 6 \\
September & 17 & 7 & 9 & 4 \\
October & 11 & 8 & 8 & 5 \\
December & 0 & 0 & 9 & 45 \\
November & 0 & 0 & 11 & \\
Total & 169 & 85 & 101 & \\
\hline
\end{tabular}

or lost. The individuals which were sighted but not captured were also counted. The capture of $A$. euphratica was easier than that of $J$. jaculus. More than $40 \%$ of the total number of $A$. euphratica was caught by pouring water into burrows, but only $15 \%$ of. $J$. jaculus was captured by this way. Captured jerboas were placed in cages and given some food. The next morning they were killed, weighed and sexed and the standard body measurements were taken. The skins were cleaned from fat and the moulting as indicated by black patches on the inside of the skin was studied. Some of the animals were kept in the cages for one week in order to observe the behavioral attitudes.

\section{RESULTS AND DISCUSSION}

1. Activity. The activity during the different months of the year was expressed by the number of animals seen and trapped during the fourhours periods of observations. Number in Table 1 indicates, that in the 
region under study the dominant jerboa is. Allactaga euphratica. The high number of $A$. euphratica were observed during the period FebruaryOctober. No Euphrates Jerboas were observed from November to January.

The seasonal activity of Jaculus jaculus shows quiet a different picture. This species is seldom active during the warm months and only few specimens were sighted or trapped during warm period. It may by explained by the resistance of Allactaga euphratica to high temperature and this of Jaculus jaculus to the low temperature (Fig. 1 shows the temperature, relative humidity and rainfall during 1977 in the studied area). Happold (1967) in his study of Jaculus jaculus in Sudan mentions that it seemed to be abundant in October to December. This pattern of activity during the year can be explained as an adaptation

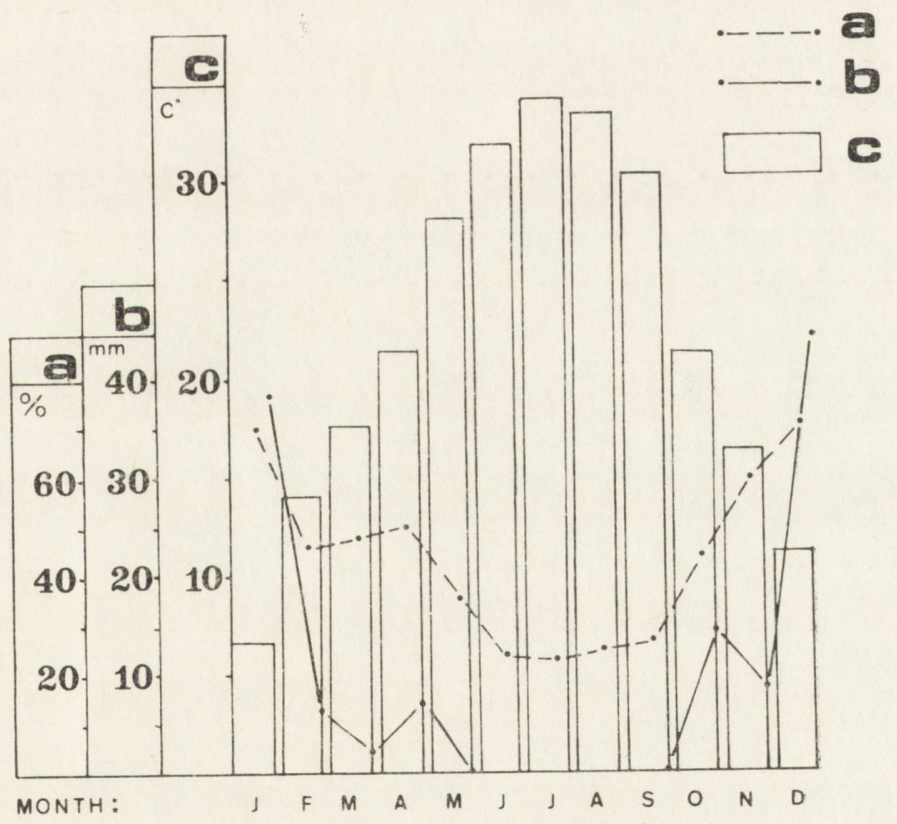

Fig. 1. Climatic factors during 1977 in Samara.

a. Monthly average relative humidity in $\%$; b. Monthly rainfall in $\mathrm{mm}$; c. Monthly average temperature in centigrades.

to the life in the desert either by aestivation or by spending the days in burrows without summer sleep.

It has to be noted that first meetings of Allactaga euphratica were 1.20-2 hours after sunset, whereas for Jaculus jaculus they were seen already one hour after sunset. At the beginning of the dark period $A$. euphratica could not run fast and was very easy to catch, while $J$. 
jaculus was active and could run quickly during all periods of: observations.

2. Moulting. All the skins from each month were studied in order to demonstrate the monthly situation of the process. It can be seen from Fig. 2 that the moulting in Allactaga euphratica begins centrally and progresses forward and backward. True moulting was observed only in Juiy. This means that the animals were moulting once a year.

Fig. 3 shows the moulting in Jaculus jaculus. No moulting was observed during all the months except in September and October.
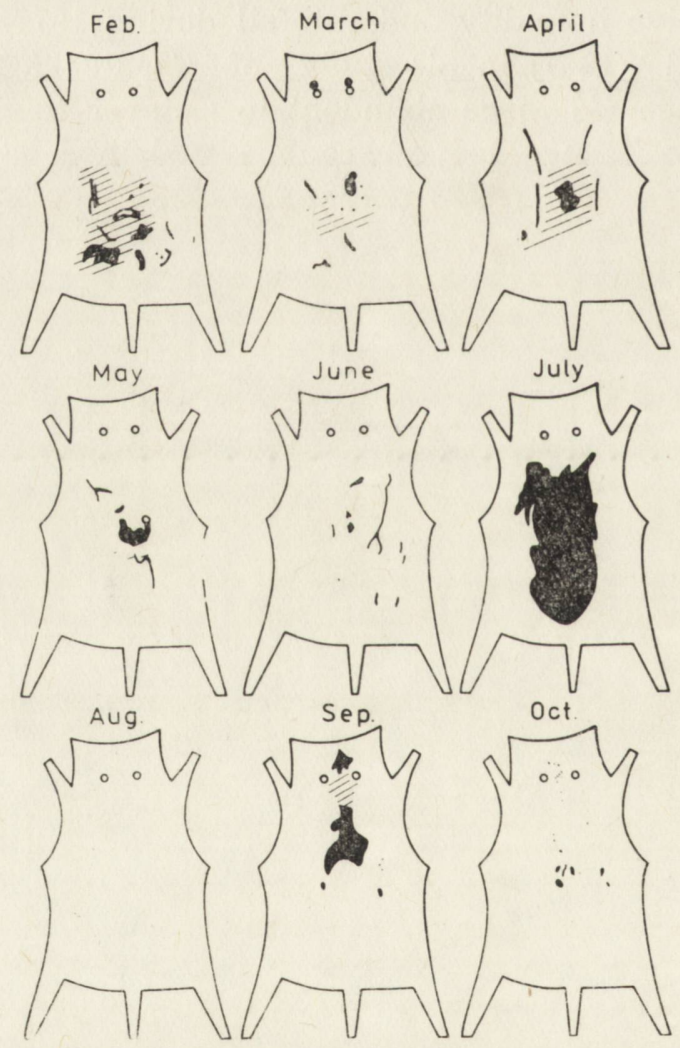

Fig. 2. Moulting in Allactaga euphratica. Typical picture of the inner side of the skin in different months.

Moulting begins rather on the back and progresses anteriorly. The Lesser Jerboa was moulting also once a year. During other months we observed small black spotes on the inner surface of the skin, but these spots cannot be taken as an indicator for moulting during another time of the year because of their limitation.

3. Fighting and aggressiveness. To study this aspect of behavior the animals were put into cages in four different combinations: 
(a) Allactaga euphratica only in the cage;

(b) Jaculus jaculus only in the cage;

(c) A. euphratica and J. jaculus in one cage;

(d) A. euphratica, J. jaculus and Meriones lybicus Lichtenstein, 1823 in one cage.

In the first and second combination new animal introduced in the cage stopped in one place waiting for attack. In this time the old inhabitant began to move from one place to another without physical
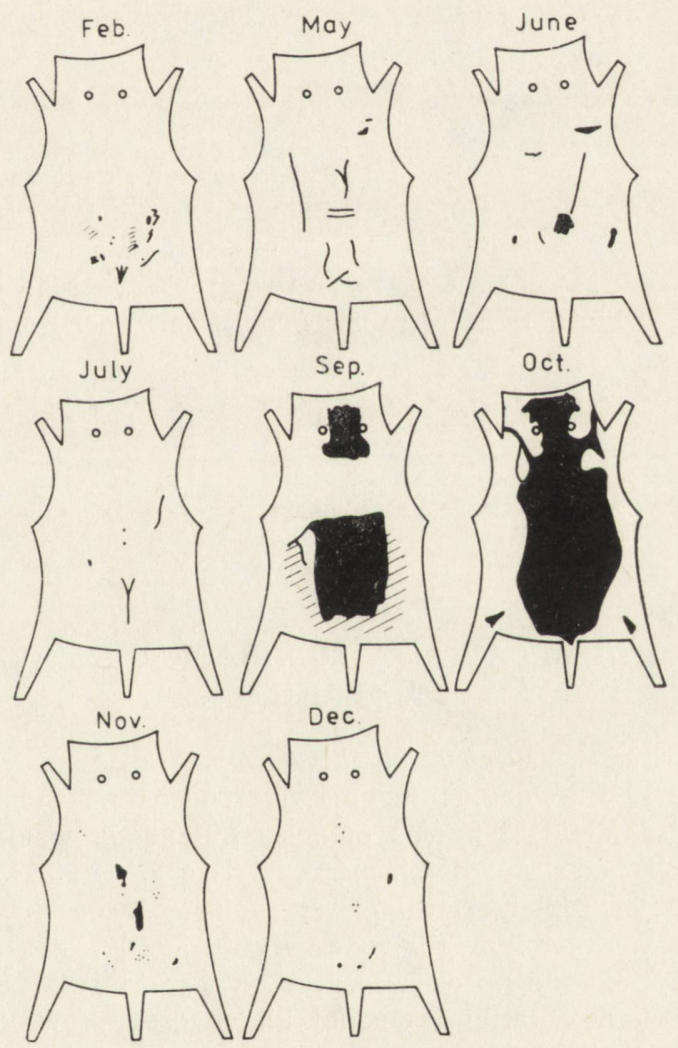

Fig. 3. Moulting in Jaculus jaculus. Typical picture of the inner side of the skin in different months.

contact with the new individual. Then they began to emit different types of sounds. After about $30 \mathrm{~min}$. the jerboas became peaceful. Several times during the night we heared sounds but fighting did not occur.

In the third and fourth combination fighting was observed and the next morning wounded, killed and partly eaten animals were found. The killed and sometimes eaten animals were Jaculus jaculus only and 
the wounded were Allactaga euphratica. The wounds were on the tigh and abdomen. Meriones libycus seemed to be the most aggressive, followed by $A$. euphratica.

\section{REFERENCES}

1. A t a lla h S.I., 1967: International Jordan Expedition 1966. IBP/CT Section, Mammalia, London, 56-63.

2. Happold D.C.D., 1967: Biology of the jerboa, Jaculus jaculus butleri (Rodentia: Dipodidae) in the Sudan. J. Zool., London, 151: 257-275.

3. Harrison D.L., 1972. The Mammals of Arabia, vol. 3. Lagomorpha, Rodentia. Ernest Benn Ltd.: 1-670. London.

4. Ha t t R.T., 1959. The Mammals of Iraq. Misc. publ., Mus. of Zool., Univ. of Michigan, 106: 1-113.

5. Kadhim A.H., Nadachowski A. \& Rzebik-Kowalska B., 1977: Review of present knowlegde of Iraqi mammals. Bull. Biol. Res. Cent., Baghdad, 6: $1-31$.

6. Lew is R.E., Lewis J.H. \& Harrison D.L., 1965: On a collection of mammals from Northern Saudi Arabia. Proc. Zool. Soc. London, 144, 1: 61-74.

Accepted, September 4, 1978.

A. H. KADHIM, A. M. MUSTAFA i H. A. JABIR

\section{UWAGI O BIOLOGII ALLACTAGA EUPHRATICA I JACULUS JACULUS W IRAKU}

Badano biologię dwu gatunków Dipodidae występujących w Iraku: Allactaga euphratica Thomas, 1881 i Jaculus jaculus (Linnaeus, 1758). Badania przeprowadzono w okolicy Samary, $122 \mathrm{~km}$ na północ od Bagdadu w ciągu roku 1977. Comiesięczne obserwacje nad aktywnością wykazały, że $J$. jaculus jest rzadko aktywny w okresie gorącym (lipiec-sierpień), natomiast $A$. euphratica nie wykazuje aktywności w okresie chłodnym (listopad-styczeń). Oba gatunki linieją raz w roku, A. euphratica w okresie lipca, J. jaculus od września do października. Obserwacje polegające na umieszczaniu w jednej klatce osobników każdego $\mathrm{z}$ dwu ba Janych gatunków, osobników różnych gatunków i osobników Dipodidae z gryzoniem Meriones lijycus Lichtenstein, 1823 wykazały, że wśród osobników tego samego gatunku nie dochodziło do walk. Przy kombinacji różnogatunkowej miały miejsce walki prowadzące niekiedy do śmierci, przy czym najbardziej agresywny był Meriones lybicus, a najmniej Jaculus jaculus, który zwykle padał ofiarą agresywności pozostałych. Przeprowadzone badania są pierwszymi obserwacjami nad biologią Dipodidae w Iraku. Autorzy przytaczają także nowe dane o rozmieszczeniu tych gatunków. 